\title{
Oral Aesthetics and the Power of Symbols in the Plays of Derek Walcott and Bate Besong
}

\author{
Emmanuel Nchia Yimbu \\ Higher Teachers Training College Yaounde, \\ Department of English, PhD in Postcolonial Literature, Part-Time Lecturer, Cameroon
}

\begin{abstract}
Although song and dance are independent art, they are being employed adequately in today's theatrical production as dramatic elements. This paper examines the relevance of songs as an aspect of oral aesthetics in the plays of Derek Walcott and Bate Besong. It also argues that like any other aspect of drama, Walcott and Besong succeeded in using songs and dances to play the triple roles of informing, educating and entertaining. Furthermore, this paper stresses the importance of symbolism in revealing the playwrights aesthetic ideologies. The playwright's attribute symbolic meaning or significance to setting, characters, objects, events, actions and relationships with the principal intention of commenting on the deteriorating nature of their various postcolonial societies.

Framed on the basis of the New Historicist assumption that, every text of literature reflects both within and without itself. The analyses in this paper, reveal that, in their attempts to conceive an independent national cultural identity, the playwrights use songs and symbolic vocabularies that are recognisably indigenous or at least different from European representations, but yet intelligible within a global grammar of post-war politics. The various songs and symbols that permeate the works under study, play multiple roles and carry various meanings if read within the context of the postcolonial societies they all set out to represent. The playwrights succeeded in crystallising songs and symbols into veritable instruments of conscientisation and revolution.
\end{abstract}

Keywords: aesthetics; songs and dance; symbolism; conscientisation.

UDC 78.01

LCC Subject Category: ML385-429

DOI: http://dx.doi.org/10.22178/pos.15-9

\section{Introduction}

The use of songs and dance as dramatic expressions are definitely not new to postcolonial writers but what differentiates one writer from the other is the purpose for which such songs are meant for. It should, however, be noted that, although song and dance are independent arts, there are being used adequately in today's theatrical production to play significant roles as aspects of oral aesthetics. The various songs and symbols that permeate the works under study play multiple roles and carry various meanings if read within the context of the postcolonial societies they all set out to represent. It is important to mention here that though songs and dance do not constitute the only aspects of oral aesthetics, this paper limits itself to the examination of songs and dance.

\section{Literature Review}

A. S Akinuli Olumide stipulates in "Elements of Theatre" that the use of songs in dramatic pro- duction can be divided into two major categories: incidental and dramatic music [22]. A. S. Olumide sees incidental (song) as that used to set mood, to underscore or heighten emotions. In a dramatic production, incidental music is not an integral part of a play but can be introduced prior to the beginning of it to establish the appropriate mood and atmospheric conditions within a performance. By not being an integral part of the production, we mean it is not composed for the play. It is used as background music in a dramatic production.

Dramatic music on the other hand, A. S. Olumide further stresses, is an integral part of the play's action. He quotes Brockett who argues that "it is used most extensively in opera and musical comedy or in plays that employ music and song to comment on the action in a Brechtian manner" [22]. Brockett, Olumide opines, goes further to state that "in such works the music is usually written to meet the specific demands of the script, and the overall effect would be altered se- 
riously were the music to be omitted". A. Olumide concludes his analysis on the use of song and dance in theatre by stating that [22, p. 114]:

Some of the functions of music in a dramatic production are to first and foremost establish or enhance mood and create expectation. Secondly, it is also used to establish the level of probability. That is, what the audience are watching is not a real life situation but an artistic imagination of the playwright's view. Thirdly, it can also be used to characterise melody, rhythm and tempo. Fourthly, music can be a medium for the ideas and lastly, music can be pleasurable in itself, for it is enjoyable quite apart from its dramatic uses.

Walcott and Besong use song and dance for multiple reasons. Song and dance constitute an important element of satire in the works of Walcott and Besong. There are not only used for entertainment but constitute a veritable instrument for conscientisation, satire and revolution. The messages and meanings embedded in most of the songs one comes across in the plays under study validate H. L. B Moodys' claims in Literary Appreciation that, "Literature, which entertains us, does not keep us for long in the other world of fantasy or unreality. The greatest satisfaction to be found in literature occurs where it bring us back to the realities of human situations, problems, feelings and relationships" [19, p. 2-3]. Moody's view here is very much contrary to that of Peter Abety who in "The Literary Podium and the Political Pulpit: Medium and Message in Anglophone Cameroon Drama" emphasises on the strength of the literary podium over message (political pulpit) [1]. He believes plays that overtly address the problems of the people are less successful from the aesthetic stand point and their survival as literary masterpieces becomes short-lived. According to P. Abety, audiences go to the theatre not to get solutions to social and political problems but rather for entertainment. As he puts it, "they want to be in the literary podium and only sink into the political pulpit long afterwards in quiet reflection" [19, p. 16]. Songs from Walcott's and Besong's perspective become not just instruments for entertainment as P. Abety emphasises but are mostly used to expose and satirise the realities of the human situation as suggested by Moody.

Walcott uses songs in Dream on Monkey Mountain (Henceforth referred to as Dream) [31], O Babylon!, Ti Jean and His Brothers (Henceforth
Ti Jean), The Sea at Dauphine (Henceforth The Sea and Pantomime to express the modes of the Caribbean and St. Lucian society. Drawn from his native background, songs express the hopelessness and despair of the black man and the exploitative nature of the colonialist. Most of the songs in Dream are songs of lamentation [27, p. 212-213]:

\section{Contour: Mouma mooma}

Your son in de jail a ready

Your son in de jail a ready

Take a towel and

Brand you belly...

I pass by the police station, Nobody to sign de bail bond...

This song exposes the judicial system in the Caribbean Island where the basic rights of the people like the right to bail are violated. The inmate's inability to obtain bail inflicts psychological pain not only on the victims but on their families as well. The above song, while exposing Walcott's allegiance to Creole in terms of its wordings, is at the same time, a lampoon on the West Indian judicial system.

Also, Walcott uses songs to attack certain societal vices like marginalisation, caused by the multiracial nature of the St. Lucian society. For instance, the song "I' don't know what to say this monkey won't do..." [27, p. 222-223]. The Monkey in this song refers to the black man. Derek Walcott in this song attacks the black man for his passive acceptance. Walcott seems not to be happy with the blacks who suffer injustice from the oppressor without complaining and yet seem to do nothing to improve their situation.

Furthermore, though living in a hopeless world, the Caribbean's are very hopeful. Their hopeful dreams are exposed through singings. In songs, the oppressed hopes for a place of peace, love and comfort. Ti-Jean hopes for external happiness in the song below [30, p. 162]:

To the door of breath, you gave the key,

Thanks you, lord

The door is open, and I step free,

Amen, Lord...

Cloud after cloud like silver stair

My lost ones waiting to great me there

With their silent faces, and starlit hair Amen lord...

This song equally highlights Walcott's religious vision. The song proves that there's happiness 
after every successful struggle like is exemplified with the case of Ti-Jean.

As in Ti-Jean and Dream, Walcott Pantomime and $O$ Babylon! have been described as musicals because music is one of the most prominent dramatic devices. At the beginning of the play Pantomime, Harry in a song gives the purpose for their Pantomime [28, p. 132):

It's our Christmas Panto,

it's called: Robinson Crusoe.

We're awfully glad that you've shown up,

it's for kiddies as well as for grownups.

Our purpose is to please:

so now our magic wand ...

Just picture a lonely Island

and a beach with its golden sand.

There walks a single man

in the beautiful West Indies!

Harry's song sets the pace for the performance as it acts as a formal introduction to the play. The play as Harry's song above denotes is about "Robinson Crusoe" and is set in the "beautiful West Indies". Nevertheless, it will be an academic oversight to see the play as Harry stipulates only as an instrument of entertainment. This is because, beneath every song used in the course of the play, there is a denotative meaning meant to send a strong message. Walcott uses songs and dance in Pantomime to narrate the story of slavery and its traumatic effects on the Afro-West Indians.

Equally, it is as a result of the excessive use of songs and dance in $O$ Babylon! that forced Sule Mombara to conclude that the play is " a musical which fuses the tenets of European musical drama into the tense political day to day life of the Rastafarians" [18]. It is for this reason that almost all the dramatic dialogue in $O$ Babylon! is rendered in the form of songs because song and dance are part and parcel of Rastafarian existence. The following song, sung by Four Horsemen in act one of the play exposes a series of topical issues relating to the lives and believes of the Rastafarian cult [29, p. 163]:

Jah is I-and-I salvation.

Jah shall gather all the nations,

Wide as ocean is his patience

and deep with wisdom like the sea,

the secret sea,

the shining sea of

Jah love and peace.

Jah love and peace.
This song has to do with themes of liberty and freedom and "Jah" refers to Emperor Haile Selassie whom the Afro-West Indians consider as their saviour. It is hoped that the coming of Jah which is the main theme in the play will bring salvation, peace and love to the Rastafarians. The use of reggae to emancipate the Jamaicans was the driving force behind the music of Bob Marley and Peter Torch. $O$ Babylon! can, therefore, be described as a music in which Walcott uses the Jamaican culture, seen through the use of the Jamaican vernacular, Creole, mime, song and dance to re-assert his Afro-West Indian identity.

Like Derek Walcott, one thing that makes Besong an outstanding playwright is his ability to use songs for multiple purposes. In Besong's The Most Cruel Death of the Talkative Zombie (Henceforth Zombie), Beasts of No Nations (Henceforth Beasts), Requiem for the Last Kaiser (Henceforth Requiem) Once Upon Four Lepers (Henceforth Lepers) and The Banquet the playwright like Walcott, uses song and dance to comment on the postcolonial politics of corruption, tribalism, misrule, dictatorship, embezzlement and greed. Besong incorporates satire, confessions and buffoonery to comment on the state of affairs in postcolonial Cameroon. Most of Besong's songs in Zombie carry titles that are quite symbolic. Some of the songs includes: "The Leper's Anthem" [5, p. 5], "Ballad of a Party Cadre" [5, p. 9], "Song of the Youthful Militant" [5, p. 29], "Song of the Great Fatherland" [5, p. 60], "Ballad of the Civilian Junta"[5, p. 51] and "Song of the Party Stooge" [5, p. 51]. The following song "Ballad of a Party Stooge" carries a lot of meaning within the context of postcolonial Cameroon [5, p. 9]:

Curse to those who mock

A messiah

We'll caress their skulls

In the sand paper hands

of the Mantoum enqueter ...

We'll scatter

The human manure

of those who hate a messiah

Whose sensitive organs, we

Plunked.

In the balancoire

Of Foumban ideological

Corvee (sic), whose

Sensitive organs

We manured

At the Foumbam

Ideological corve 
Curse to those who mock him.

We will machine-gun

Them from

The rear.

Eternal curse

To those who hate him

We will

Bazooka them

At Tignere.

For we'll not let those

Who hate him

For no reason smirk

With delight

Over his sorrow...

Amandha! Power!

This song is a threat of death to the head of state's enemies and critics. The images of pain and torture also emerge "we will caress their skulls ... whose sensitive organs we plunked ... machine gun them ... bazooka them". These tactics are employed by dictators to frighten and intimidate the masses from rising to dissension or opposing the autocratic regime. Names of places like Mantoum and Tignere all carry with them, images of torture and violence as they served as notorious torture in prisons in the days of the former president Amadou Ahidjo's regime. Reference is also made to the historical Foumban conference and in terms of comparison, this song is very similar to that of "The Road after Foumban" in The Banquet. A song which gravitates on the Foumban conference and its disappointing outcome.

Also, Bate Besong in Lepers equally makes use of songs in an attempt to criticise postcolonial leadership. The song "The Vanguard of the Party" in Lepers, for example, is a satire on the oppressive and dictatorial nature of postcolonial leadership. The song reveals a lot in terms of meaning and imagery [10, p. 55-66]:

We are the vanguard

of the party,

We are

The vanguard of our party

We will twist flesh

We will maim

Bodies, just wait ...

We will break them

And surely we

Will bring them to their knees

Do you know that we have

Unlimited fire-power?

Doyou know ...
Like must of Besong's songs, this song ridicules the autocratic and dictatorial nature of postcolonial leadership. Comments like "we will maim bodies, break them, bring then to their knees", all echoes an atmosphere of torture and pain. The rhetorical question at the end of the song "do you know that we have unlimited powers? Only emphasises how oppressive Mbokaya's regime is.

Conversely to the above songs which are full of images of pain, torture and intimidation, Besong also uses songs as a booster to encourage the masses to resist and fight the forces of oppression. To do this, Besong at times borrows from children's songs to spur the masses to action. The songs: "Okokoriko: Oya/ Okokoriko: Oya, Juju dong come Oya!" in Zombie [5], Minimini Minimini/O Minimini / Talkam no fear... You fear you go di..." in Beasts [6] and "Tumbu tumbu/Bos kalaba/ Titi mbala poom" in The Banquet [8], respectively are all used to incite the population to action. These are children's songs that are very popular in the Anglophone Cameroon, easily draw the attention of the masses and are easily identified. Besong incorporates them in his plays because they awaken the consciousness of the masses. Childish as some of these songs may seem, they carry with them lots of meaning. "Talkam no fear..." for example is a song that emphasises on the importance of collective action and eliminates the spirit of fear by openly criticising a bad system.

Another example of a song used as a warning to the dictatorial regimes is that sung by Woman in The Banquet [8, p. 170-171]:

Ten alien eyes

Cannot be compared

With one's eyesight

Ten alien eyes

Cannot be compared

With one's eyesight...

The eye that have beheld the ocean

Can no longer be afraid of the lagoon ...

We do not use for leprosy

The herbs that are

For Ihasa fever

We do not lick

The hands

That are soaked

In gore

And blood ...

In terms of dramatic significance, this song makes excessive use of proverbs and the numerous proverbs are a call on the masses to stand up 
and fight for their freedom. From the above songs, one realises that some of them are used to praise the head of state, to threaten his critics and distracters and to mobilise the masses to take action. The songs, in one way or the other, re-enforce the central thematic preoccupations in the plays and are used not only to satirise the society's leadership but also to conscientise the masses. Besong's wish therefore is [13, p. 101]:

For a leadership that is made up of front-line nationalist with a steady resilience, hone in democratic zeal, and who will propel the Cameroonian people to redefine their individual as well as their natural focus and aspiration.

From there analyses so far, it can be argued that Walcott and Besong use songs not only to entertain but to satirise with the aim of revamping their societies. Besides songs and dance, the playwrights equally use stage directions, contrast, historical, biblical and literary allusions, a play within a play, ringing of the bell, buffoonery, dump shows and the stream of consciousness technique to expose the plight of the masses and to mock the nauseating autocratic leadership that characterises their societies. Symbolism equally constitutes Walcott's and Besong's aesthetic reservoir and like songs, it plays an important role in exposing the playwrights' aesthetic ideologies.

\section{Result and Discussion}

Some postcolonial leaders, especially in Africa, considered the works of most committed dramatists as subversive to their regimes. Consequently, for fear of banishment as was the case in many regions, dramatists resorted to writing plays where the social commentary was not so direct, but the characters and incidences were highly symbolic. Walcott's and Besong's ability to shock, provoke and "inspire, marginalised social groups to rise above their limitation by challenging the conditions of their oppression" [23, p. 7], lies party in their use of symbolism. Symbolism is an important literary device in the artistic communication of the playwrights' ideology. The emergence of absurdist drama with its emphasis on symbolism equally inspired these playwrights. The playwrights attribute symbolic or significance meaning to settings, characters, objects, events, actions and relationships. As a revolutionary alternative, Walcott and Besong avoid conventional symbols (symbols whose meanings are widely recognised) and make excessive use of contextual symbols. Most of the symbols used by the playwrights gain their symbolic meaning only within the context of the specific stories they set out to tell.

Symbolism is a valuable literary ingredient in Walcott's Dream. Characters, incidents, actions and events carry with them symbolic meanings. The most prominent use of symbolism in Dream is in Makak's dream. As Lloyd Brown has suggested, it is not difficult to accept the play's revolution as a dream, a vision which symbolically projects the revolutionary potential of Makak [12]. In other words, Dream symbolically analysis all that exist in Makak's mind. Makak's dream thus be-comes a metaphor of the realities that characterised the relationship between Black West Indians and their White Masters. Thus, many critics have interpreted Dream as a metaphorical work in which the oppressed consciences of a colonised society is symbolised through the hallucination of Makak, an ageing charcoal maker and vendor.

As critics have pointed out, those victimised by globalisation in Walcott's Dream try to adjust to the dominant culture of the West by transforming, reinterpreting and indigenizing it. In Dream, critics have noted that this adjustment involves a shift from the mundane everyday world to the abstraction of the sacred. Robert Fox and Lloyd Brown, although taking different approaches, both underscore the play's dream element and metaphoric dimension. Brown compares Dream to Leroi Jone's The Slave and illustrates that both plays are revolutionary and combine symbolism with fantasy. Walcott's play, however, clarifies The Slave for critics who dis-miss it as "naïve and suicidal and the author as a hysterical monomaniac", insisting instead on the transcultural unity of black American and Caribbean experience. Fox, in turn, emphasises on the mythological aspect of Walcott's drama; arguing that dream goes beyond redeeming the downtrodden to dramatise "the disparities between a consciousness that is creative and metaphoric, and one that is straight forward and imprisoning" [14, p. 200]. Makak's dream, which is collective and universalised according to Fox, liberates Makak by allowing him to outgrow and discard external values and thereby rediscovers his personal roots. Robert Hammer, on his part, says what is "original in Walcott is the use of his manifold voice, his particular combination of imagination and experience" [15, p. 180]. Walcott argues, sees Makak as a potential warrior, repressed by slavery. 
Besides Makak's dream, characters in Dream equally carry symbolic meaning. Makak, Souris and Tigre symbolise the West Indian masses. Their problems are what the West Indian masses are going through in the hands of their leaders. Also, Corporal Lestrade is a symbol of oppression and dictatorship. He ridicules Makak and his followers as backward savages and proudly upholds his masters' standards. Gloating over his presumed superiority, he proves through interrogation that Makak is an ape, an imitator who must be told how to behave and what to do. Like the true dictator that he is, Lestrade commands absolute power and considers himself superior. For example, when the play opens with a prologue, Makak is being led to spend the night in jail by Corporal Lestrade the mulatto, who symbolises the enthusiastic custodian of British law. He arrests Makak for being drunk and disorderly and for breaking Feliciene Alcinder's cafe. In jail, Makak meets the two habitual felons, Tigre and Souris who join Corporal Lestrade in elaborating on his offence. They mime a court scene which equally becomes very symbolic, in which Makak is tried, convicted and sentenced with the Corporal acting as Prosecutor and Defense put together, while the felons act as judges. After a whole range of exercises variously commanding Makak to 'turn about,' 'go on his knees,' stand up! Sit down! Or up on the bench! ' [15, p. 222-223], Lestrade declares that, the aim of the exercise is to "Prove that the prisoner is capable of reflexing, obeying orders, and of understanding justice" [15, p. 223].

At this level of depiction alone and through the character of Corporal Lestrade, Walcott engages in a sort of satire that other postcolonial writers see as the best way to ridicule enthusiastic, but rather naive and half-baked perpetrators of colonial rule and legality in newly independent states. The depiction is reminiscent of Wole Soyinka's portrayal of the Nigerian village school teacher, Lakunle, in The Lion and The Jewel [27]. Besides the numerous wits which punctuate his speech and phrases like 'sale of self-said bags', or 'is reputed to have', Lestrade repeats the phrase 'all the Sunday' twice in this passage, and the combination of these misnomers makes him the quintessential Lakunle figure, who cannot effectively challenge the forces of reactionary tradition no matter how hard he tries. Lestrade, therefore, becomes a symbol of those non-progressive forces that continue to hinder the emancipation of the West Indians. However, his conversion at the end of the play equally becomes important within the context of the play as it symbolises the realisation of his West Indian identity. Walcott in this act is suggesting that the West Indians must depend on their fellow brothers for their own emancipation.

Makak's beheading of the White Apparition, in Dream, is also of great significance. This act becomes a symbol of liberation not only to Makak but to the entire West Indian community including Corporal Lestrade who later on realises himself and becomes a native and Makak's staunchest convert to Africa. Makak becomes a symbol of courage and a manifestation of an acutely perceived Caribbean working man of immense courage.

Furthermore, the spider's image in Dream is also very symbolic. When Moustique impersonates Makak in the market, he discovers that he is afraid of spiders, which is witnessed once more by Basil, who then torments him with the creature, and uses the image of a moonlight road as seeming to have legs "splayed like a spider". The sinister qualities of the spider's image are really associated with Moustique's fear, which are both a convincing example of folk belief and a suggestion of Moustique's lack of capacity to deal with the thought or association of death. Moustique is a fearful person who therefore survives by his wits and if necessary by deception and betrayal.

Symbolically still, Makak's name is interchangeable with a monkey and the site or location of the play's second Eden is Monkey Mountain. Within the framework of the coloniser's misnaming, the animal/savage symbols associated with Makak and other principal characters, Tigre (Rat), Souris (Mouse), Moustique (Mosquito) are a reinforcement of the myth of the noble savage. However, as Walcott observes himself, his own use of this animal symbolism operates on a deeper level of 'meaning', not unconnected with the strength of the stories about devils and gods and the cunning of certain figures. Some of these figures have been read in their literal senses by the playwright himself but many others enhance the pattern or cultural and ideological signification of his entire discourse in Dream on Monkey Mountain. In Afro-American profane discourse according to Henry Louis Gates "there are thousands of 'toasts' of the signifying Monkey, most of which commence with a variant of the following formulaic lines [2, p. 138]: 
Deep down in the jungle so they say

There's a signifying monkey down the way.

There hadn't been any disturbin' in the jungle for quite a bit,

For up jumped the monkey in the tree one day and laughed,

'I guess I'll start some shit.

Thus, in adopting the figure of the monkey, Walcott makes a subtle recourse to what Gates describes further as "the ironic reversal of a received racist image of the black as simian-like, the Signifying Monkey (or) he who is dwelling at the margins of discourse, ever-punning, ever troping, ever embodying the ambiguities of language - is our trope for repetition and revision, indeed, is our trope for chiasmus itself" [2, p. 188]. In coming down from Monkey Mountain, Makak acts like the proverbial monkey 'who guessed he'll start some shit'.

Ostensibly the definition of the signifying Monkey is not complete if it is not linked with its ancestral homeland. Walcott's adaptation of these folk elements is not along the pattern of works merely informed by the past but one that holds the past itself in profound dialogue. Integral parts of these dialogues are the amorphous relationship between the slave buyer and the seller which constitute the distinctive features of West Indian postcoloniality with lots of signification.

Similarly, as in Dream, Walcott's Pantomime and Ti-Jean can be read as symbolic representations of the different stages of slavery and slave trade and its impacts on the Afro-West Indian masses. Harry and Planter in Pantomime and Ti-Jean respectively symbolise the oppressors or slave masters, while Jackson and the three Jeans and their mother stand for the oppressed West Indian masses. Still, in terms of significance, these two plays can be considered as the long and on ending battle between good and evil.

Furthermore, characters, concepts and setting becomes very symbolic in Walcott's The Sea. The sea serves both as a place for death and at the same time, the Afro-West Indian source of survival. It represents the unpredicted forces of nature. Set beside a string of reminiscences as in Dream, the reminiscences symbolises the active presence of a past as the characters' awareness of their history is what gives meaning to their lives and attest to their identity, first as individuals, then as a community. For example, Afa, the wise old man remembers his colleagues and fel- low fishermen who lost their lives in the sea. The humour and pathos of these reminiscences by Afa evoke the memory of his dead colleagues and captures in a symbolic mannerism, the fated lives of the Afro-West Indian fishermen. When the young Jules (who symbolises the Afro-West Indian youth) decides to take to the sea, Afa looks out to the sea and say "last year Annuelles, and Bolo, and this year Hounakin and one day, tomorrow, you Gracia, and me... and Augustin ... [2, p. 80]. Given this background of absurdity, the characters in the play are intensely aware of the ironies and perplexities of their lives and the existential impasse with which they have to contend. Symbolically, they are all imprisoned in their circumstances and their awareness of this imprisonment leads them to acts of rebellion as we see in the rebellion against institutionalised religion. The examples above reveal that Walcott's language is blended with images that help to communicate his ideology.

Bate Besong's ingenuity as a playwright is partly revealed in his ability to use scatological images, metaphors and symbols that are pregnant with meanings. S. Ambanasom argues that Besong gives his work the force of topicality because he sometimes uses direct and recognisable references [3]. Besong uses a reference to make clear his revolutionary ambitions and it is certainly for this reason that "some people fled in terror when Bate Besong's play was performed in Yaounde". People fled because Besong's play Butake stipulates, "Puts a mirror to our faces so that we can see how full of filth and shit the refection is" [2, p. 19]. Jean-Stephane Biatcha's reactions after the performance of Besong's Beasts is a clear testimony of the power of Besong's shock therapy $[11$, p. 115]:

... After enduring this play, I had to get up, by the way of protest, accompanied by Chief of Service for Student's Associations and Cultural Clubs, to quit the hall just at the time when Mr. Besong was concluding his fiery exhortations at the end ... this experiences which, I must admit, is shocking and disappointing ...

The manner and profundity of Besong's theatre, as expressed by Biatcha validates Victor Hugo's observations that, "the multitude must not come out of the theatre without taking with them some austeric and profound moral message" [16, p. 6]. Beasts, Requiem, The Banquet, Lepers and Change Waka are plays that address issues of power politics and dictatorship and can be con- 
sidered the issues raised in the plays, as a direct confrontation to Agidigidi's, Epeng Ebho', Nouayed's and Ednouay's leaderships.

In terms of setting, there is a series of similarities between the world of the text and that of a particular historical period and physical place. Commenting on Requiem, George Nyamndi says "The two worlds can confront each other without difficulty" [20, p. 38]. Iduote the capital of Agidigi, is Etoudi read backwards. Etoudi being the presidential palace in Yaounde, the capital of Cameroon, one will not be wrong to conclude that the story of Agidigidi, a country characterised by tyranny, tribalism and greed, is symbolically that of Cameroon. Equally, one can say that Requiem constructs a revolutionary consciousness in order to overthrow a dictatorship in a neo-colonial African setting. It is obvious that Iduote where the play is set, reveals the unmistaken intent of the writer, at launching a direct critique on the current dictatorship in Cameroon.

Similarly, in Beast and The Banquets the city of Ednuoay, Yaounde read backward and Nouayed where the stories are set is the capital city of the Republic of Cameroon. The shit metaphor that Besong uses to punctuate the facts in Beasts resonates with lots of significations. Besong uses shit and stench metaphors to make a statement about a nation held hostage by beastlike leaders, who because of their inexhaustible greed reduce every other thing in society to "filth" and "shit". The imagery in the world of Beasts is compellingly repellent as one follows the squatting and grunting Narrator's graphic description of one of the toilets [16, p. 123]:

I am the alumnae, a genius in the academic cosmos of shitology (squats as if answering call of nature). This is the prolegomena of the brim-stone, the Nitric acid, the effluvium, the gangrene, the syphilitic concoction, and the mycobacterium leprae of modern trade dealers.

The Night-Soil Men's indecent exposure of their buttocks to "foul the air" is such an absolutely grotesque and repellent device of artistic representation. As N. Ambe mentions, that does not only shock the audience, but also pricks and appeals to their collective conscience to begin to want to arrest such a state of depravity and callousness [4]. This dramatic device, which in itself is very innovative, is meant not only to expose the decadent nature of post-independence Cameroon but most especially, to attack the social conventions that characterises the society like greed, embezzlement and corruption.

Since shit becomes the main product in society, its pungent smell looms freely and overwhelmingly everywhere in the theatre space. So, in depicting the conflicting relationship and social and economic imbalance in Besong's Ednouay, the dramatist, in almost the same manner as the Ghanian writer Ayi Kwei Armah in The Beautyful Ones are Not Yet Born, invests in scatological and unsettling images. As noted above, the image of shit buckets, faecal equipment and lavatories that dominate this play, and the very present of sound and rhythm of buckets of excrement being loaded and offloaded by Night-Soil-Carrier, who symmetrically squat and foul the air, capture the picture of a society enmeshed in the decay and darkness of a bucket toilet. It is equally this shocking new way of communicating the human condition, that so shocked some members of the audience when the play was premiered in Amphi 700 of the University of Yaounde 1, that some of them fled out of the hall. It is this same shit that the Night-Soil-Men used to storm Aadingingin's marble palace at the end of the play. In terms of experimentation, especially as far as metaphors, images and symbols are concerned, Beasts confirm Besong as the best experimental Anglophone Cameroon dramatist, as his language is carefully crafted with symbols that will leave no reader indifferent. The moral rottenness of the world of Ednuoay is what Besong conveys successfully through the image of shit and all the smell it emits.

One aspect that makes Besong very different from some of his contemporaries is his use of real names of people, places and concepts with symbolic meaning. Besong in the ALA Bulletin argues that the New Deal politics has been a disruptive phenomenon. It excludes rather than includes social element and therefore, a writer in such a society must "question history, question environment and question people in authority", and to do this successfully according to him, "the writer uses his talent... to call things by their names..." [16]. Besong in Beasts, Requiem, The Banquet, Zombie, Lepers and Change Waka makes references to real concepts like plebiscite, referendum, reunification and integration. He uses names like Jacque Chirac, John Ngu Foncha, E.N Endeley, S.A George, Um Nyobe, Ernest Quandie, A.N. Jua, P.M. Kale, Z.A. Abendong and places like lake Nyos, Sonara, Tchollere, Konden- 
gui, Mantoum and Foumban amongst many others. The above are all concepts, names and places with dire connotation. For example, Lake Nyos is a lake in the Menchum Division, of the North West Region of Cameroon, where thousands of Anglophone Cameroonians died, alongside their animals, during the August 26, 1985 gas explosion. An action considered by the Anglophone Cameroonians as a conscious act by the Francophone leadership to satisfy their political ambitions. Sonara on its part is the oil refinery company located in Limbe, the South West region of Cameroon. It is an epitome of French Capitalist interest in Cameroon since Cameroonians; especially South Westerners have no say in the running and enjoy little or no benefits from their tapped resources. It equally emphasises Anglophone marginalisation. Foumban is historically symbolic in that it is in Foumban that the 1962 conference to change the country into a Federal government system was held. The terms of this conference were violated in 1972 by President Ahidjo, an act which Anglophone Cameroonians consider as betrayal. Kodengui, Mantoum and Tchollerie are notorious torture prisons. These names are all linked to the political history of Cameroon as exemplified in chapter two of this study. The above incidences justify George Ngwane's claims that, to better understand Besong's plays, "one needs to be current with historical events, and abreast of socio-political trends" [20, p. 20].

Furthermore, the title of Beasts, Requiem, Zombie and Change Waka are equally very symbolic. A "beast" is an animal that is cruel and brutal and by referring to Ednuoay's leadership as "beasts of no nation", Besong is in a way saying that, just as beasts, Ednuoay's leader, Aadingingin is not only cruel and brutal to the masses, symbolised by the Night-Soil-Men but is equally insensitive to the plight of the masses. The pain and suffering that he inflicts on the masses are enough to qualify him as a beast.

In Requiem, "Requiem" symbolises the definite passing away of a man and his time. It presupposes a death song, a funeral salute to the dead, an elegy. In the play, the song is address to Akhikikrikii, a ruler, the last Kaiser. Just as Akhikikrikii, Kaisers were monarchs with established authoritarian and dictatorial regimes. When Besong talks of "Requiem for the Last Kaiser", he is in effect saying that Akhikikrikii is the last of such rulers in Agidigidi. Thus, the title an- nounces the purging of the society from all the ills incorporated in despotism. Also, in terms of signification, the play opens with Akhikikriki (the supreme leader) in a coffin, symbolising the imminent death of dictatorship. He epitomises tyranny and thus bears the brunt of Besong's satire. With his head barely sticking out, he begins a long monologue, more or less fantasising about his enormous power. His words like those of his cohorts are couched in obnoxious images of conceit and power. A "Zombie" is a blood drinking creature that is often associated with violence and torture.

Moreover, in terms of characterisation, Requiem, Beasts, Lepers, Change Waka and The Banquet present characters with symbolic meanings. Akhikikrikii, Aadingingin, Mbozo'o, Mbokaya and Mfawbaheb Gnockor are symbols of dictatorship and tyranny in Agidigidi, Ednuoay, Nouayed and Epeng Ebho respectively. The French Ambassador and the Swiss Banker in Requiem symbolise the colonial influence in Africa and the perpetrators of political, economic and socio-political exploitation. Absalom Antangana symbolises French assimilation and religious hypocrisy. Woman and Student in Requiem, and the NightSoil Men, Cripple and Blind man in Beasts and Change Waka in Change Waka respectively all symbolise the downtrodden masses. Equally, the words "Anglos" and "Frogs" as used in the two plays represent the Anglophone and the Francophone Cameroonians. With regards to the use of suggestive names, Mfawbahep, as Ambanasom stipulates means a gang leader in the playwright's native Kenyang language. This, together with the fact that, His Excellency Gknockor Gknockor is referred to in the play as "loot dispenser" [9, p. 32] makes the head of state a great thief, expanding thus the thematic interpretation of the play. "Change Waka" is a kind of democratic watch-dog, a defender of the transparent ballot boxes at a time when the dominant and fashionable "walking style" is rigging. Change Waka therefore represents the trend of democratic salvation that is yet to gather steam.

More still, Requiem, Beasts and The Banquet can symbolically be considered as a battle between power and violence on the one hand and necessity and hope on the other. Whereas the regime and its mentor struggle to protect and strengthen the tyrannical status quo, the people, on the other hand, struggle to bring it down through a revolt. The masses are held in the darkness of slavery 
for too long and now a need is felt for the overthrow of the force that have reduced them to slaves. This new need is symbolised by Woman and Student in Requiem, and the Night-Soil Men in Beasts, Change Waka in Change Waka and Belle in The Banquet. They all symbolise revolt against tyranny. In Requiem, Woman's determination and will to combat hunger, injustice and exploitation and her refusal to give evil any further chance is highlighted in her climatic exchange with Etat-Major Andre Abessolo, "Career toe-breaker and torturer" [7, p. 21]:

Our children won't be hungry anymore. We won't see our old folks all trusted up with rheumatism of injustices, the water of exploitation running down their faces, we are here to destroy the robbers in paradise. They have created their own Ruben Island. Their separate Amenities Act but soon all that will be over.

The above declarations open our minds to the truth of the day to day activities in postcolonial Cameroon. Like rheumatism, which attacks the entire body system, injustice has eaten deep into the fabrics of Besong's fictive society. In fact, the symbolism in Zombie, Requiem, Beasts, Change Waka, The Banquet and Lepers documents the realities of post-colonial Cameroon. It emphasises the long history of political, social and economic domination of the Anglophones whom, Besong indicates in most of his plays, have been the greatest losers and victims in the formation and evolution of the Cameroon nation at decolonisation. Nevertheless, the metaphor in the plays is also a call for the suffering masses and their greedy leaders to improve their human condition, uplift their society from the darkness and rot that have held it hostage. J. M Kariuki puts it in a more emphatic manner when he submits that only a new future would redeem the African masses from their past suffering [17, p. 230]:
Our leaders must realize that we have put them where they are. Not to satisfy their ambitions nor so that they can strut about in fine clothes and huge Cadillac as ambassadors and ministers. But to create a new society in which everyone will have an opportunity to educate himself to his fullest capabilities, in which no one will die or suffer through lack of medical facilities, and in which each person will earn enough to eat for himself and his family

\section{Conclusion}

From the above, it is evident that songs and dance and the use of symbolism become an important ingredient in the literary works of Walcott and Besong. The strength of their literary commitment lies in their use of historical, physical and recognisable references with symbolic meaning. In their attempts to conceive an independent national identity, the playwrights concentrated on developing symbolic vocabularies that are recognisably indigenous or at least different from European representation, yet intelligible within a global grammar of post-war politics. Thus, Walcott and Besong use the good springs of their cultures and societies, to incorporate them in songs in an attempt to expose, satirise and offset the borrowed influences of Europe. Their backgrounds as poets partly account for the dense images that run through their works. As concerns similarities, the dramas of Walcott and Besong are a combination of tragedy and comedy, plays that can, to a certain extent, be considered as "problem plays" because they project through songs and symbols, social issues which are meant to raise the awareness of their audience.

\section{References}

1. Abety, P. (2013). The Literary Podium and the Political Pulpit: Medium and Message in Anglophone Cameroon Drama. In H. N. Eyoh, A. Azeyeh, \& N. Lyonga (Eds.), Critical Perspectives on Cameroon Writing (pp. 339-360). Mankon, Cameroon: Langaa Research\&Publishing GIG. Retrieved from https://muse.jhu.edu/chapter/959402

2. Abodurin, F. (2008). Blackness: Culture, Ideology and Discourse (2nd ed.). Ibadan, Nigeria: Dokun Publishing House.

3. Ambanasom, S. A. (2010). Education of the Deprived. Anglophone Cameroon Literary Drama. N. d.: Langaa Research\&Publishing GIG. Retrieved from https://muse.jhu.edu/book/16847 
4. Ambe, N. H. (2007). Change Aesthetics in Anglophone Cameroon Drama and Theatre. Bayreuth: Pia Thielmann and Eckhard Breitinger.

5. Besong, B. (1986). The Most Cruel Death of the Talkative Zombie: a Faery Play in Three Parts with a Revelry at a Requiem. N. d.: Nooremac Press, 1986.

6. Besong, B. (1990). Beasts of No Nation: a docu-drama. Limbe, Cameroon: Nooremac Press.

7. Besong, B. (1991). Requiem for the Last Kaiser. Calabar: Centaur Publishers.

8. Besong, B. (1994). The Banquet: a historical drama. Makurda, Nigeria: Editions Ehi.

9. Besong, B. (2001). Change Waka and His Man Sawa Boy. Yaounde: Edition CLE.

10. Besong, B. (2003). Once Upon Four Great Lepers. Yaounde: Edition CLE.

11. Biatcha, J. S. (1991). A la Haute Attention de Monsieur le Chancelier de L'université de Yaoundé. Challenge Hebdo, 45, 11.

12. Brown, L. (1993). Dreamers and Slaves - The Ethos of Revolution in Walcott and Leroi Jones. In R. D Hammer (Ed.), Critical Perspectives on Derek Walcott (pp. 174-193). Washington, D. C.: Three Continents Press.

13. Fandio, P. (2005). Anglophone Cameroon Literature at the Cross- Roads: Pierre Fandio in Conversation with Cameroonian Writer, Bate Besong. ALA Bulletin, 30(2), 90-104.

14. Fox, E .R. (1993). Big Night Music: Derek Walcott's Dream on Monkey Mountain and the "Splendour of Imagination". In R. D. Hammer (Ed.), Critical Perspectives on Derek Walcott (pp. 193-202). Washington, D. C.: Three Continents Press.

15. Hammer, R. D. (Ed.). (1993). Critical Perspectives on Derek Walcott. Washington, D. C.: Three Continents Press.

16. Kilo, A. (1992). Anglophone Cameroon Drama 1969-1991 (Doctoral thesis). Leeds, UK: University of Leeds.

17. Clough, M. S. (1998). Mau Mau Memoirs: history, memory, and politics. Boulder, Colorado: L. Rienner.

18. Mombara, S. (1993). O Babylon! Where it Went Wrong. In R. D. Hammer (Ed.), Critical Perspectives on Derek Walcott (pp. 268-285). Washington, D. C.: Three Continents Press.

19. Moody, HLB. (1968). Literary Appreciation: A Practical Guide to The Understanding and Enjoyment of Literature in English. London, UK: Longmans.

20. Ngwane, G. (1993). Bate Besong (or the Symbol of Anglophone Hope). Limbe: Nooremac Press, 1993.

21. Nyamndi, G. (2003). Requiem for the Last Kaiser: A Promethean Reading. In A. Edward (Ed.), Between and Within: Essays in Commonwealth and Postcolonial Literature (pp. 20-42). Yaounde, Cameroon: Saagrapf.

22. Olumide, A. S. (1999). Elements of Theatre (Twayne's World Authors Series). Retrieved from Thomson Gale's Online Database: http://www.gale.com/

23. Orwell, G. (2005). Why I Write. New York, USA: Penguin Books.

24. Porter, A. (1998). A Word from the Incoming ALA BULLETIN Editor. ALAB, 24(4), 42.

25. Soyinka, W. (1963). The Lion and The Jewel (2nd ed.). Oxford, USA: Oxford University Press.

26. Walcott, D. (1958). The Sea at Dauphin: a Play in One Act. [Mona, Jamaica]: Extra-Mural Dept., Univ. College of the West Indies.

27. Walcott, D. (1966). Malcauchon, or, The Six in the Rain. Trinidad \& Tobago: U.W.I., Extra-Mural Department, Port-of-Spain, Trinidad \& Tobago: Busby's Printerie.

28. Walcott, D. (2002). Pantomime. Alexandria, VA: Alexander Street Press.

29. Walcott, D. (2003). O Babylon! Alexandria, VA: Alexander Street Press.

30. Walcott, D. (2003). Ti Jean and His Brothers. Alexandria, VA: Alexander Street Press.

31. Walcott, D. (2014). Dream on Monkey Mountain and Other Plays. New York, USA: Farrar, Straus and Giroux. 


\title{
Словесная эстетика и сила символов в пьесах Дерека Уолкотта (Derek Walcott) и Бейта Бесонга (Bate Besong)
}

\author{
Emmanuel Nchia Yimbu \\ Higher Teachers Training College Yaounde, \\ Department of English, PhD in Postcolonial Literature, Part-Time Lecturer, Камерун
}

\begin{abstract}
Аннотация. Хотя песня и танец являются самостоятельными видами искусства, в настоящее время они используются определенным образом в современной театральной постановке как отдельные драматические элементы. В данной статье рассматривается актуальность песен как аспекта устной эстетики в спектаклях Дерека Уолкотта (Derek Walcott) и Бейта Бесонга (Bate Besong). В статье утверждается, что, как и в других аспектах драмы, авторам удалось с помощью песни и танца выполнить тройную функцию информирования, обучения и развлечения. Кроме того, в этой статье подчеркивается важность символики в раскрытии эстетической идеологии драматургии. Драматурги добавляют символического значения декорациям, персонажам, объектам, событиям, действиям и взаимоотношениям с целью комментирования ухудшающей среды различных постколониальных обществ.

На основе предположений Новейшей истории, любой литературный текст отражает внутреннее и внешнее содержание эпохи. Анализ, представленный в этой статье, показывает, что в своих попытках представить независимую национально-культурную самобытность, драматурги используют песни и символическую лексику, которые являются узнаваемыми среди коренных жителей или, по крайней мере, отличаются от европейских версий, но понятны в рамках глобальной грамматики послевоенной политики. Различные песни и символы, пронизывающие анализируемые произведения, выполняют сразу несколько ролей и несут различные значения, будучи прочитанными в контексте тех постколониальных обществ, которые они представляют. Драматурги достигли успеха в кристаллизации песен и символов в инструменты формирования сознания и революции.
\end{abstract}

Ключевые слова: эстетика; песни и танцы; символизм; формирование сознания.

УДК 78.01

LCC Subject Category: ML385-429

DOI: http://dx.doi.org/10.22178/pos.15-9

(C) E. N. Yimbu

Статья получена 20.10.2016, принята 28.10.2016, опубликована оnline 30.10.2016 